\title{
SUPERVISI KLINIS DAN SITUASI KINERJA GURU DI SEKOLAH/ MADRASAH
}

\author{
Subur \\ Dosen Jurusan MPI IAIN Syekh Nurjati Cirebon \\ Email.subur54@gmail.com
}

\begin{abstract}
Abstrak
Guru adalah pendidik profesional yang mempuyai tugas, dan fungsi dan peranan penting dalam mencerdaskan kehidupan bangsa. Guru profsional mampu berpar-tisipaasi dalam pembangunan nasional untuk mewujudkan insan Indonesia yang bertaqwa kepad Tuhan Yang Maha Esa, unggul dalam IPTEK, memiliki jiwa estetis, etis, berbudi luhur, dan berkepribadian. Sehingga mereka sebagai guru harus memi-liki empat kompetensi yaitu, pedagogic, kepribadian, social dan profesionalisme.

Beberapa kerangka teori, metode, dan analisis, dan pemetaan kognitif, masih banyak dibutuhkan untuk membantu meng-atasi dan menyatakan praktek supervisi. Menurut arti katanya, supervisi dapat diterjemahkan dengan "melihat dari atas", atau " melihat dari kelebihan",jadi searti dengan pengawas, tetapi dengan pengertian yang agak berbeda dari "mengawas" sebagai "controlling". Supervisi meskipun mengandung arti dan sering diterjemahkan sebagai pengawas atau mengawas, tetapi pada prinsipnya supervisi mempunyai arti khusus yaitu " membantu dan turut serta dalam usaha-usaha perbaikan dan peningkatan mutu"

Agar proses supervise klinis dapat berjalan dengan baik dan lancer perlu kreteria serta teknik tertentu. Kreteria dan teknik pertemuan pendahuluan terdiri penetuan hal-hal yang perlu dinilai oleh supervisor terhadap guru, penetuan ini adalah mengadakan pertemuan dengan suasana menyenangkan,tidak mengancam, dan menakuti.Kepala Sekolah/ Madrasah sebagai individu yang bertanggungjawab di Sekolah/Madrasah mempunyai kewajiban untuk berusaha agar semua potensi yang ada di lembaganya dapat dimanfaatkan sebaik-baiknya demi tercapainya tujuan yang diharapkan. Oleh karena itu supervise Kepala Sekolah/Madrasah terhadap guru menjadi salah satu factor penting dalam meningkatkan mutu pendidikan di sekolahnya/madrasahnya.
\end{abstract}

Kata kunci : Supervisi klinis, kinerja guru 


\section{A. Pendahuluan}

Suatu kondisi belajar yang optimal dicapai, jika guru mampu mengatur siswa dan sarana pengajaran serta dapat mengendalikannya dalam suasana yang menyenangkan untuk mencapai tujuan pembelajaran. Kadang-kadang pengaturan yang dimaksud bersifat lebih langsung berkenaan dengan penyampaian pesan pembelajaran. Oleh karena itu tugas guru pada umumnya cukup kompleks sehingga dituntut sejumlah pengetahuan dan perangkat ketrampilan tentang jabatan atau profesinya. Tugas seorang guru di kelas khususnya mengajar, dikerjakan sendiri dalam kelas, sehingga permasalahan yang dihadapi terkadang diselesaikan sendiri.

Pekerjaan memberikan bantuan kepada guru dalam pertumbuhan jabatannya disebut supervisi dan orang yang berfungsi memberi bantuan tersebut biasanya disebut supervisor dalam hal ini adalah kepala madrasah. Dalam sejarah perkembangannya mula-mula tugas supervisi dibebankan kepada "orang" yang ditunjuk untuk mengunjungi sekolah (madrasah) bagi kepentingan pengawasan mutu. Mereka mengawasi atau menginspeksi sekolah (madrasah) dan guru untuk menilai sarana sekolah serta kemajuan belajar siswa. Namun dalam pelaksanaanya membantu guru dalam memperbaiki cara mengajarnya bukan merupakan perhatian utama para pengawas tersebut.

Supervisi sebagai aktivitas yang dirancang untuk memperbaiki pengajaran pada semua jenjang persekolahan, berkaitan dengan perkembangan dan pertumbuhan anak. Supervisi juga merupakan bantuan dalam perkembangan dari belajar mengajar dengan baik. Dengan demikian supervisi pendidikan yang diberikan kepala madrasah kepada guru untuk mendukung keberhasilan belajar siswa

Pada pihak lain kebanyakan guru tidak suka disupervisi walaupun itu merupakan suatu keharusan serta bagian dari proses pendidikan dan pekerjaan mereka. Perkembangan selanjutnya kepala madrasah juga dapat berfungsi sebagai supervisor bagi para guru yang berada dibawah tanggungjawabnya. Pokok pikiran yang terkandung dalam konteks supervisi ini adalah memberikan tekanan pada proses pembentukan dan pengembangan profesionalisme guru dengan maksud memberikan respons terhadap perhatian utama serta kebutuhan guru yang berhubungan dengan tugasnya.

Pembentukan profesional guru yang bermaksud untuk menunjang pembaharuan pendidikan serta untuk mengatasi merosotnya suatu pendidikan harus dimulai terutama dengan mengadakan perhatian dalam cara mengajar guru di kelas. Dengan upaya perbaikan dan penyempurnaan cara mengajar guru di kelas diharapkan siswa dapat belajar dengan baik sehingga tujuan pendidikan dan pengajaran dapat tercapai secara maksimal.

Keterampilan mengajar guru merupakan salah satu jenis keterampilan yang dikuasai guru, sebabnya dengan keterampilan mengajar, guru dapat mengelola proses pembelajaran dengan baik yang berimplikasi pada peningkatan kualitas lulusan sekolah

Pada umumnya, keberhasilan dan kegagalan pendidikan dan pembelajaran akan lebih banyak ditentukan oleh keterampilan mengajar secara profesional tenaga kependidikannya. Untuk itu tenaga kependidikan dituntut untuk profesional dalam melaksanakan tugasnya. Seorang tenaga kependidikan yang profesional akan senantiasa melakukan sesuatu yang benar dan baik (do the right thing and do it righ), Konsekuensinya adalah guru selalu mengembangkan profesionalismenya melalui peningkatan pendidikannya.

Pendidikan dan pembelajaran di Madrasah bukanlah pekerjaan yang mudah, tetapi perlu teknik dan strategi yang tepat, agar dapat berhasil dengan baik. Keberhasilan pendidikan dan pembelajaran di Madrasah dapat dilihat dari perubahan sikap dan tingkah laku 
siswa, prestasi yang diraih dan kemampuan kompetensi secara sehat.

\section{B. Supervisi Klinis di Sekolah/Mad- rasah \\ Konsep Supevisi Secara Umum}

Menurut konsep kuno supervisi dilaksanakan dalam bentuk " inspeksi" atau mencari kesalahan. Sedangkan dalam pandangan modern supervisi adalah usaha untuk meperbaiki situasi belajar mengajar. Menurut arti katanya, supervisi dapat diartikan dengan "melihat dari atas" atau "melihat dari kelebihan". Jadi supervisi searti dengan pengawas, tetapi dengan pengertian yang agak berbeda dari " mengawas " sebagai "controlling”. Supervisi meskipun megandung arti dan sering diterjemahkan sebagai pengawas atau mengawas, tetapi pada prinsipnya supervisi mempunyai arti khusus yaitu membantu dan turut serta dalam usahausaha perbaikan dan mutu pendidikan, Seful Sagala (2006:228). Oleh karena supervisi kepala madrasah dalam membantu guru-gurunya dalam mengajar sehingga dapat membantu siswa agar lebih baik dalam kegiatan belajar mengajar.

Secara umum supervisi berarti upaya bantuan yang diberikan kepada guru dalam melaksanakan tugas profesionalnya, agar guru mampu membantu para siswa dalam belajar untuk menjadi lebih baik dari sebelumnya. Supervisi merupakan suatu teknis pelayanan profesional dengan tujuan utama mempelajari dan memperbaiki bersama-sama dalam membimbing dan mempengaruhi situasi belajar mengajar yang lebih baik.

Supervisi pendidikan diperlukan, hal ini dilatar belakangi oleh berkembangnya science dan teknologi, adanya tuntutan hak asasi manusia, pertumbuhan ekonomi dan kemakmuran yang tidak merata, tubuhnya birokrasi dan sistem yang bertingkat, membantu dan membina guru-guru yang kurang bermutu, pertumbuhan jabatan, peraturan dan tuntutan negara, kultural, filosofis, psikologis dan sosiologis, disamping itu secara historis teori supervisi memiliki pengembangan landasan teori, menurut Sergiovanni dan Starrat dalam buku Administrasi Pendidikan Kontemporer, Seful Sagala (2005:229), menyatakan bahwa untuk memahami keperluan pekerjaan yang unik dalam supervisi pendidikan dilihat dari posisi dan masalahnya perlu memberikan beberapa perhatian khusus terhadap sifat ilmu pengetahuan maupun ilmu terapan yang mendukung kedudukan supervisi pendidikan. Konsepsi teori dan praktek tradisional tidak mampu lagi menangkap kompleksitas dan kepekaan kebijakan dan praktek supervisi pendidikan, karena itu diperlukan pendekatan yang lebih dinamis.

Beberapa kerangka teori, metode analisis, pemetaan kognitif msaih dibutuhkan untuk membantu membatasi dan menyatakan praktek supervisi. Untuk ini ia harus mengetahui jalannya usaha, mengetahui kelemahan-kelemahannya dan kelebihan-kelebihannya yang bekerja dan cara-cara kerjanya. Untuk mengetahui semua hal itu supervisor harus melakukan penelitian atau pengamatan terlebih dahulu. Jika sudah diketahui kelemahankelemahannya, barulah dicarikan cara-cara memperbaiki dan meningkatkan situasi belajar mengajar. Sepervisi Pendidikan yang dilakukan oleh personel sekolah (kepala) kepada orang dewasa atau mengubah operasi sekolah dengan cara yang secara langsung dapat mengubah dan mempengaruhi proses pengajaran guna meningkatkan kualitas belajar murid.

Supervisi sebagai aktivitas yang dirancang untuk memperbaiki pengajaran pada semua jenjang persekolahan, berkaitan dengan perkembangan dan pertumbuhan anak, supervisi juga merupakan bantuan dalam perkembangan dari belajar mengajar dengan baik. Dengan demikian supervisi diberikan kepada guru untuk mendukung keberhasilan belajar siswa. Definisi-definisi supervisi ini mengandung unsur-unsur tujuan yang hendak dicapai dan memiliki latar belakang adanya perubahan sosial. 
Supervisi meskipun mengandung arti atau sering diterjemahkan sebagai pengawas, namun mempunyai arti khusus yaitu “ membantu " dan turut serta dalam usaha-usaha perbaikan dan meningkatkan mutu. Disamping itu supervisi mempunyai fungsi penilaian (evaluation) dengan jalan penelitian (research) dan merupakan usaha perbaikan (improvemen).

Dari rumusan supervisi tersebut diatas dapat diartikan bahwa supervisor (kepala madrasah) berada pada posisi yang unik dalam pembelajaran, sebab tugasnya amat strategis untuk mempengaruhi keefektifan interaksi dalam pelayanan belajar oleh guru. Karena itu praktek supervisi di Madrasah didasrkan pada salah satu atau kombinasi dari manajemen ilmiah, hubungan manusia dilihat dari aspek psikologis, sosiologis dan komunikasi.

Hubungan manusia berakar dari gerakan administrasi demokratik yang memandang guru sebagai manusia seutuhnya dalam hak-hak mereka. Sehingga untuk memperoleh pengajaran yang baik dan berkualitas, perlu adanya sistem supervisi yang efektif.

\section{Konsep Supervisi Klinis}

Supervisi Klinis pada dasarnya hampir sama dengan supervisi pendidikan hanya saja jika supervisi klinis lebih ditekankan pada proses pembelajaran. Mengajar adalah suatu kegiatan yang dapat dikontrol dan dikendalian (Controlable anda maganeble), diamati (obseravable) dan terdiri dari komponen-komponen keterampilan mengajar yang dapat dilatih secara terbatas (isolater). Jadi supervise klinis adalah untuk memperbaikai dan meningkatkan keterampilan mengajar guru dikelas. Dalam hubungan inilah supervise klinis merupakan kunci untuk meningkatkan kemampuan professional guru. Oleh karena itu tujuan utama supervisi klnis adalah;

a. Menyediakan guru yang professional

b. Mendiagnosis, yaitu membantu memecahkan masalah mengajar c. Memantu guru menggunakan strategistrategi mengajar

d. Sebagai dasar untuk promosi lebih lanjut

e. Membantu guru bekerja secara professional sehingga kariernya meningkat

f. Perhatian utama pada kebutukan guru.

\section{Teknik Supervisi Klinis}

Supervisi pendidikan adalah untuk meningkatkan situasi dan proses belajar mengajar berada dalam rangka tujuan pendidikan nasional Bab II Ps 3;

"Pendidikan nasional berfungsi mengembangkan kemampuan dan membentuk watak serta peradaban bangsa yang bermartabat dalam rangka mencerdaskan kehidupan bangsa, bertujuan untuk berkembangnya potensi peserta didik agar menjadi manusia yang beriman dan bertakwa kepada Tuhan Yang Maha Esa, berakhlak mulia, sehat, berilmu, cakap, kreatif, mandiri, dan menjadi warga negara yang demokratis serta bertanggung jawab", (UU Sisdiknas No.20 Tahun 2003)

Teknik supervisi klinis dipandang bermanfaat untuk merangsang dan mengarahkan perhatian guru-guru terhadap kurikulum dan pengajaran adalah teknik individual dalam rangka pengembangan proses belajar mengajar meliputi kunjungan kelas, observasi kelas, percakapan pribadi, saling mengunjungi kelas dan menilai diri sendiri, dsb.Menurut Sutisna (1983:226) dalam buku Administrasi Pendidikan Kontemporer, dinyatakan bahwa teknik-teknik supervisi klinis, antara lain;

Kunjungan Kelas. Kunjungan kelas sering disebut kunjungan supervisi yang dilakukan kepala Sekolah/ Madrasah yaitu teknik yang paling efektif untuk mengamati guru bekerja, alat, metode, dan teknik mengajar tertentu yang dipakainya, dan untuk mempelajari situasi belajar secara keseluruhan dengan memperhatikan semua faktor yang mempengaruhi 
pertumbuhan murid. Dengan menggunakan hasil analisis observasinya, ia bersama guru dapat menyusun suatu program yang baik untuk memperbaiki kondisi yang melingkari belajar mengajar di kelas. Sudah tentu, kunjungan kelas dilakukan agar efektif, hendaknya dipersiapkan dengan teliti dan dilaksanakan dengan sangat hati-hati dengan disertai budi bahasa yang baik. Pada umumnya kunjungan kelas hendaknya diikuti oleh pembicaraan individual antara kepala sekolah/ Madrasah dengan guru.

Pembicaraan Individual. Pembicaraan individual merupakan teknik supervisi yang sangat penting karena kesempatan yang diciptakannya bagi kepala sekolah/ madrasah untuk bekerja secara individual dengan guru sehubungan dengan masalah-masalah profesional pribadinya. Masalah-masalah yang mungkin dipecahkan melalui pembicaraan individual bisa macam-macam masalah yang bertalian dengan mengajar, dengan kebutuhan yang dirasakan oleh guru, dengan pilihan dan pemakain alat pengajaran, teknik dan prosedur, atau bahkan masalah-masalah yang oleh kepala sekolah/ madrasah dipandang perlu untuk dimintakan pendapat guru. Apapun yang dijadikan pokok pembicaraan, ia mewakili teknik yang sangat baik untuk membantu guru mengembangkan diri dan tumbuh kedalam pekerjaan.

Demonstrasi mengajar. Demonstrasi mengajar merupakan teknik berharga pula. Rencana demonstrasi yang telah disusun dengan teliti dan dicek lebih dulu, dengan menekankan pada hal-hal yang dianggap penting atau pada nilai teknik mengajar tertentu, akan sangat membantu. Pembicaraan sehabis itu bisa menjelaskan banyak aspek. Suatu analisis observasi adalah perlu untuk mengetahui apa saja yang telah dicapai dan apa pula yang masih perlu diperbaiki.

Kunjungan kelas antar guru. Sejumlah studi telah mengungkapkan bahwa kunjungan kelas yang dilakukan guru-guru diantara mereka sendiri adalah efektif dan disukai. Kujungan ini biasanya direncanakan atas permintaan guru-guru. Teknik ini akan efektif lagi jika tiap observasi diikuti oleh suatu analisis yang berhati-hati.

Pengembangan Kurikulum. Perencanaan dan penyusunan pengembangan kurikulum menyediakan kesempatan yang sangat baik bagi partisipasi guru. Pentingnya relevansi kurikulum dengan kebutuhan murid dan masyarakat bagi pemeliharaan dan peningkatan kualitas pendidikan di negara kita diakui. Tapi dalam praktek sekolah-sekolah secara individual tidak banyak melakukan usaha untuk menyesuaikan dan mengembangkan kurikulum standar itu dengan murid dan masyarakat yang terus berubah. Terserah kepala sekolah/ madrasah untuk menciptakan perhatian dan keinginan bagi pekerjaan penting dan terus menerus ini.

\section{Kinerja Guru di Sekolah/Madrasah Pengertian Guru}

Secara umum, makna guru yang sangat sederhana dan mudah diingat adalah orang yang memberikan ilmu pengetahuan dan keterampilan kepada peserta didik. Guru dalam pengertian ini tidak terfokus kepada guru yang secara formal mengajar dan memberikan pelajaran tertentu di sebuah lembaga pendidikan.

Makna yang lebih spesifik tentang guru adalah sebagaimana yang terdapat dalam Undang-undang guru dan Dosen Nomor 14 tahun 2005, Bab I, Pasa 1, sebagai berikut: Guru adalah pendidik profesional dengan tugas utama mendidik, mengajar, membimbing, mengarahkan, melatih, menilai, dan mengevaluasi peserta didik pada pendidikan anak usia dini jalur pendidikan formal, pendidkan dasar, dan pendidikan menengah".

\section{Persyaratan Guru.}

Dengan diberlakukannya undangundang RI No.14 tahun 2005 tentang guru dan dosen, serta PP No.19 tahun 2005 
tentang Standar Nasional Pendidikan secara resmi profesi guru telah disejajarkan dengan profesi lainnya sebagai tenaga profesional. Sebagai tenaga profesional guru harus memenuhi sejumlah persyaratan, sebagai berikut;

Memiliki kualifikasi akademik. Kualifikasi akademik adalah ijazah jenjang pendidikan akademik yang harus dimiliki oleh guru sesuai dengan jenis, jenjang, dan satuan pendidikan formal di tempat penugasan. Kualifikasi akademik ini ditunjukkan dengan ijazah yang merefleksikan kemampuan yang dipersyaratkan bagi guru untuk melaksanakan tugas sebagai pendidik.

1) Bagi guru pada anak usia dini, mempunyai kualifikasi pendidikan minimal Diploma IV atau Sarjana S1.

2) Bagi SD/MI, mempunyai kualifikasi pendidikan minimal Diploma IV atau Sarjana S1.

3) Bagi Guru MTs/SMP, mempunyai kualifikasi pendidikan minimal Diploma IV atau Sarjana S1.

4) Bagi Guru SLTA/MA, mempunyai kualifikasi pendidikan minimal Diploma IV atau Sarjana S1.

Memiliki Kompetensi. Kompetensi guru merupakan seperangkat pengetahuan, keterampilan, dan perilaku yang harus dimiliki, dihayati, dikuasai, dan diwujudkan oleh guru dalam melaksanakan tugas keprofesionalannya. Ditampilkan melalui unjuk kerja (kinerja guru). Keputusan Menteri Pendidikan Nasional Nomor;045/U/2002, menyebutkan kompetensi sebagai seperangkat tindakan cerdas dan penuh tanggunjawab dalam melaksanakan tugastugas sesuai dengan pekerjaan tertentu. Jadi kompetensi guru dapat dimaknai sebagai kebulatan pengetahuan, keterampilan, dan sikap yang berwujud tindakan cerdas dan penuh tanggungjawab dalam melaksanakan tugas sebagai agen pembelajaran. Dalam undang-undang Guru dan Dosen Nomor 14 tahun 2005 dan Peraturan Pemerintah Nomor 19 tahun
2005 dinyatakan bahwa kompetensi guru meliputi; kompetensi pedagogi, kepribadian, sosial. Dan profesional,

1) Kompetensi Pedagogik. Kompetensi pedagogik adalah kemampuan yang harus dimiliki guru berkenaan dengan karakteristik peserta didik dilihat dari berbagai aspeknya seperti; fisik, moral, sosial, kultur, emosional dan intelektual. Hal tersebut berimplikasi bahwa seorang guru harus menguasai teori belajar dan prinsip-prinsip pembelajaran yang mendidik karena peserta didik memiliki karakter, sifat, dan interes yang bebeda.

2) Kompetensi Kepribadian. Pelaksanaan tugas sebagai guru harus didukung oleh suatu perasaan bangga akan tugas yang dipercayakan kepadanya untuk mempersiapkan kualitas generasi masa depan bangsa. Walaupun berat tantangan dan rintangan yang dihadapi dalam pelaksanaan tugas, guru harus tetap tegar .Guru sebagai pendidik harus dapat mempegaruhi kearah proses sesuai dengan tata nilai yang dianggap baik, seperti norma, moral, estetika, ilmu pengetahuan, dan disiplin. Semuanya itu akan berhasil apabila guru juga disiplin dalam tugasnya, dan member contah teladan bagi peserta didiknya.

3) Kompetensi Sosial. Kemampuan social artinya guru mampu berinteraksi dengan siapa saja, termasuk dengan masyarakat, dalam rangka pelaksanan proses pembelajaran yang efektif. Dengan kemampuan tersebut otomatis hubungan madrasah dengan masyarakat akan berjalan dengan lancer, sehingga jika ada keperluan dengan orangtua peserta didik para guru tidak akan mendapat kesulitan.

Kemampuan social guru, antara lain:
a) Dalam berkomunakasi
b) Dalam bekerja sama
c) Dalambergaul secara simpatik
d) Mempunyai jiwa yang menyenangkan


4) Kompetensi Profesional. Kompetensi Profesional yaitu kemampuan yang harus dimiliki guru dalam perencanaan dan pelaksanaan proses pembelajaran. Guru harus selalu meng -update, dan menguasai materi pelajaran yang disajikan, dan selalu mengikuti perkembangan dan kemajuan terkini tentang materi pembelajaran yang disajikan. Dalam menyampaikan pembelajaran guru mempunyai peranan dan tugas sebagai sumber materi yang tidak pernah “kering” dalam mengelola proses pembelajaran.

a) Memiliki sertifikat pendidik. Sebagai tenaga profesional guru dituntut mampu melaksanakan sistem pendidikan nasional dan mewujudkan tujuan pendidikan nasional, yaitu berkembangnya potensi peserta didik agar menjadi manusia yang beriman dan bertaqwa kepada Tuhan Yang Maha Esa, berakhlak mulia, sehat, berilmu, cakap, kreatif, mandiri, serta menjadi warga negara yang demokratis dan bertanggungjawab.

Direktorat Jenderal Peningkatan Mutu Pendidikan dan Tenaga Kependidikan telah merencanakan program peningkatan mutu. Program tersebut antara lain pelaksanaan sertifikasi guru. Tujuan sertifiasi adalah untuk meningkatkan kualitas guru yang pada akhirnya diharapkan berdampak pada peningkatan mutu pendidikan.

b) Sehat jasmani dan rohani. Jasmani yang tidak sehat akan menghambat pelaksanaan pendidikan, bahkan dapat membahayakan anak didik bila mempunyai penyakit menular. Dari segi rohani, orang gila berbahaya juga bila mereka mendidik. Orang idiot juga tidak mungkin mendidik karena mereka tidak akan mampu bertanggungjawab. Oleh itu persyaratan kesehatan dibuktikan dengan memperlihatkan keterangan dokter.

c) Memiliki kemampuan untuk mewujudkan tujuan pendidikan nasional.

Ketrampilan Mengajar Guru Menjelaskan berarti menyajikan informasi lisan yang diorganisasikan secara sistematis dengan tujuan menunjukkan hubungan. Penekanan memberikan penjelasan adalah proses penalaran siswa, dan bukan indoktrinasi. Untuk itu beberapa prinsip yang perlu diperhatikan adalah; (1) Penjelasan dapat diberikan di awal, di tengah, atau di akhir jam pertemuan, tergantung keperluan.(2) Penjelasan harus relevan dengan tujuan pelajaran, (3) Penjelasan dapat diberikan bila ada pertanyaan dari siswa atau direncanakan oleh guru. (4) Materi penjelasan harus bermakna bagi siwa, (5) Penjelasan harus sesuai dengan latar belakang dan kemampuan siswa.

Keterampilan mengajar guru merupakan salah satu jenis keterampilan yang harus dikuasai guru, sebabnya dengan keterampilan mengajar, guru dapat mengelola proses pembelajaran dengan baik yang berimplikasi pada peningkatan kualitas lulusan sekolah. Ada beberapa jenis keterampilan mengajar, Hamzah B. Uno, M. Pd, dkk (2004:193), sebagai berikut;

Keterampilan Menjelaskan. Keterampilan menjelaskan pelajaran merupakan salah satu aspek keterampilan mengajar yang penting dalam perbuatan guru. Beberapa alasan mengapa keterampilan menjelaskan perlu dikuasai, antara lain;

1) Pada umumnya interaksi komunikasi lisan di dalam kelas didominasi guru.

2) Sebagian besar kegiatan guru adalah informasi. 
3) Penjelasan yang diberikan guru sering tidak jelas bagi siswa, dan hanya jelas bagi guru sendiri.

4) Tidak semua siswa dapat menggali sendiri informasi yang diperoleh dari buku. Kenyataan ini menuntut guru untuk memberikan penjelasan kepada siswa untuk hal-hal tertentu.

5) Sumber informasi yang tersedia yang dapat dimanfaatkan siswa sendiri sering sangat terbatas.

6) Guru sering tidak dapat membedakan antara menceritakan dan memberikan penjelasan.

Keterampilan Memberi Penguatan. Memberikan penguatan diartikan dengan tingkah laku guru dalam merespons secara positif suatu tingkah laku tertentu siswa yang mungkin tigkah laku tersebut timbul kembali. Keterampilan memberikan penguatan bertujuan;

1) Meningkatkan perhatian siswa

2) Melancarakan atau memudahkan proses belajar

3) Membangkitkan dan mempertahankan motivasi

4) Mengontrol atau mengubah sikap yang mengganggu ke arah tingkah laku belajar yang produktif

5) Mengembangkan dan mengatur diri sendiri belajar

6) Mengarahkan kepada cara berpikir yang baik dan insiatif pribadi.

Disamping itu keterampilan memberi penguatan merupakan keterampilan yang arahnya untuk memberikan dorongan, tanggapan, atau hadiah bagi siswa agar mereka mengikuti pelajaran merasa dihormati dan diperhatikan. Penghargan mempunyai pengaruh positif dalam kehidupan manusia sehari-hari, yaitu mendorong seseorang memperbaiki tingkah laku serta meningkatkan kegiatannya atau usahanya. Kegiatan memberikan penguatan dalam proses belajar mengajar dalam kelas jarang sekali dilaksanakan oleh guru.

\section{Keterampilan Membuka dan} Menutup Pelajaran. Membuka pelajaran diartikan dengan perbuatan guru untuk menciptakan suasana siap mental dan menimbulkan perhatian siswa agar terpusat kepada apa yang akan dipelajari. Menutup pelajaran adalah kegiatan guru mengakhiri kegiatan inti pelajaran. Maksudnya adalah memberikan gambaran menyeluruh tentang apa yang telah dipelajari siswa, mengetahui tingkat pencapaian siswa dan tingkat keberhasilan guru dalam proses belajar mengajar.

Kegiatan membuka dan menutup pelajaran mempunyai tujuan, antara lain;

1) Menimbulkan perhatian dan motivasi siswa terhadap tugas-tugas yang dihadapi.

2) Memungkinkan siswa mengetahui batas-batas tugasnya yang akan dikerjakan

3) Siswa dapat mengetahui pendekatanpendekatan yang akan digunakan dalam mempelajari bagian-bagian pelajaran.

4) Memungkinkan siswa mengetahui hubungan antara pengalamanpengalaman yang dikuasai dengan hal-hal baru yang akan di pelajari

5) Memberikan kemungkinan kepada siswa untuk menggabungkan faktafakta, keterampilan-keterampilan, konsep-konsep yang tercakup dalam peristiwa

6) Memungkinkan siswa dapat mengetahui tingkat keberhasilannya dalam pelajaran.

Banyak faktor yang turut mempengaruhi rendahnya kualitas pendidikan. Apabila pendidikan itu dilihat sebagai suatu sistem, maka faktor yang turut mempengaruhi kualitas pendidikan tersebut meliputi (1) input mentah atau siswa, (2) lingkungan intrstruksional, (3) proses pendidikan dan (4) out put atau keluaran pendidikan. Dalam proses pendidikan di dalamnya terdapat aktivitas guru mengajar, peranserta siswa dalam belajar, sistem pengelolaan administrasi serta perilaku kepemimpinan kepala sekolah merupakan hal yang perlu 
dioptimalkan fungsinya agar kualitas pendidika dapat ditingkakan.

Salah satu factor yang menjadi tolok ukur keberhasilan sekolah adalah kinerja guru. Kinerja guru dimaksud adalah hasil kerja guru yang terefleksi dalam cara merencanakan, melaksanakan, dan menilai proses belajar mengajar yang intensitasnya dilandasai oleh etos kerja, serta disiplin profesional guru dalampem belajaran.

Madrasah di bawah naungan Kementrian Agama RI merupakan suatu organisasi yang memerlukan pengelolaan (manajemen) yang terpadu baik oleh guru sebagai pelaksana kegiatan belajar mengajar di kelas, maupun kepala madrasah sebagai pengendali kegiatan di madrasah. Koordinasi yang baik oleh kepala madrasah akan melahirkan pencapaian tujuan madrasah, serta tujuan para individu yang ada di dalam lingkungan madrasah. Di samping itu keterpaduan kinerja guru dalam melaksanakan kegiatan belajar mengajar serta penciptaan situasi yang kondusif merupakan prasyarat keberhasilan tujuan madrasah.

Dengan demikian guru dan kepala madrasah memegang peranan penting baik dalam mengelola kegiatan belajar mengajar maupun dalam mengelola manajemen yang dapat menunjang keberhasilan tujuan madrasah. Meskipun demikian aktivitas kerja guru Madrasah dalam melaksanakan tugasnya masih turut dipengaruhi oleh adanya supervisi dan motivasi kepala madrasah.

Faktor lain yang turut menentukan kinerja guru Madrasah adalah motivasi kerja. Di duga munculnya motivasi kerja yang baik dari kepala madrasah, akan melahirkan kinerja yang baik bagi guru. Seorang kepala madrasah, persoalan yang dihadapkan kepadanya adalah bagaimana menciptakan suatu situasi di mana guru dapat memperoleh kepuasan dalam melaksanakan pekerjaan untuk mencapai tujuan. Motivasi adalah proses psikologis yang terjadi pada diri seseorag akibat adanya interaksi antara sikap, kebutuhan, keputusan dan persepsi seseorang dengan lingkungannya.

Madrasah sebagai suatu organisasi yang di dalamnya terdapat personel guru, perlu dikembangkan motivasi kerjanya. Motivasi kerja dimaksud adalah suatu dorongan mental yang muncul dari dalam dan luar diri guru untuk melaksanakan tugas. Bagi guru , tugas dan tanggungjawab itu terlihat pada aktivitas pembelajaran dan administrasi sekolah yang dikerjakan akibat dorongan dari dalam diri serta dorongan yang diberikan kepala sekolah.

Supervisi dapat dipandang sebagai seni kerja dengan sekelompok orang agar memperoleh hasil yang sebenar-benarnya. Seni disini menuntut kemampuan untuk mempraktekan prinsip-prinsip hubungan antar manusia (human relation) yang baik. Dalam menerapkan hubungan antar manusia tidak ada ukuran yang pasti meyakinkan, karena setiap manusia memiliki pribadi yang unik. Oleh karena itu kepribadian merupakan suatu pertimbangan bagi supervisor dalam membentuk kerjasama yang berhasil. Madrasah sebagai lembaga yang memproses lulusan untuk menghadapai tantangan kehidupan masyarakat secara luas. Peran yang diberikan kepada madrasah harus dilaksanakan oleh tenagatenaga profesional sesuai dengan bidang tugasnya dalam pendidikan dan pengajaran.

Richard Weller dalam buku pengajaran Micro Teachig J.J Bolla (2003:123) mengatakan bahwa supervisi yang difokuskan pada perbaikan pengajaran dengan menjalankan siklus yang sistematis dari tahapan perencanaan, pengamatan, dan analisis intelektual yang intensif terhadap penampilan mengajar sebenarnya dengan

Tujuan untuk modifikasi pengajaran yang rasional. Oleh karena itu supervisi merupakan proses membantu guru memperkecil jurang antara tingkah laku mengajar yang nyata dan tingkah laku mengajar yang ideal. Supervisi juga 
dipandang suatu proses bimbingan yang bertujuan untuk membantu pengembangan profesional guru atau calon guru khususnya dalam penampilan mengajar berdasarkan observasi dan analisis data secara teliti dan objektif sebagai pegangan untuk perubahan tingkah laku mengajar tersebut.

Upaya kepala Sekolah/ madrasah dalam melakukan supervisi kepada guru harus memperhatikan beberapa unsur, antara lain;

a. Adanya hubungan tatap muka antara supervisor dan guru dalam proses supervisi.

b. Memfokuskan pada tingkah laku yang sebenarnya dari guru di dalam kelas.

c. Supervisor dan guru bersama-sama menilai penampilan guru

d. Fokus observasi sesuai dengan kebutuhan dan permintaan guru.

Sekarang ini mulai terdengar keluhan masyarakat terhadap kualitas pendidikan dan tenaga kependidikan kita pada berbagai jenjang dan jenis pendidikan yang sebenarnya merupakan refleksi dari profesionalisme tenaga kependidikan yang rendah, termasuk gurunya. Jika kita mengidentifikasi beberapa faktor pendorong dan penghambat peningkatan profesionalisme tenaga kependidikan di Madrasah, maka akan kita temukan banyak variabel. Antara lain; keterampilan mengajar guru, kualifikasi pendidikan, pengalaman, situasi dan kondisi lembaga itu sendiri. Ada beberapa faktor pendorong bagi peningkatan profesionalisme tenaga kependidikan di Madrasah dalam melaksanakan pendidikan dan pembelajaran, antara lain;

a. Mempunyai motivasi yang tinggi dalam menjalankan profesi kependidikannya.

b. Memahami tahapan-tahapan perkembangan berpikir, moral dan kepercayaan eksistensial siswa.

c. Trampil membelajarkan ilmu berdasarkan kemajuan tingkat-tingkat kognitif, afektif dan psikomotor siswa. d. Memahami bahaya de-humanisasi, perbudakan dan keberhalaan yang terkandung dalam benda-benda teknologi.

e. Pendidikan berlangsung sepanjang hayat dan secara komplementer akan sejalan dengan pendidikan pada bidang ilmu, kesenian dan kesusilaan.

Jika tenaga kependidikan memperhatikan beberapa hal tersebut, tidak mustahil pelaksanaan pendidikan dan pembelajaran di Madrasah akan berjalan lancar, sebagai hasilnya, siswa akan menjadi manusia-manusia cerdas, trampil, berbudi pekerti luhur dan bermoral.

Adapun faktor penghambat peningkatan profesionalisme tenaga kependidikan di Madrasah, antara lain:

a. Kurang terampil dan menguasai bidang ilmunya, baik secara tekstual maupun kontekstual.

b. Kurangnya imbalan yang diterima, sehingga kurang memusatkan perhatian pada tugas kependidikannya.

c. Kurangnya informasi tentang problema-problema pendidikan dan pembelajaran yang diapresiasikan di hadapan siswa.

d. Kurang menghayati makna disiplin kerja, tugas dan waktu dalam mendukung profesionalisme tenaga kependidkan di Madrasah

Dalam situasi sosial apapun, jabatan guru tetap di nilai oleh masyarakat sebagai pemberi inspirasi, penggerak dan pelatih dalam penguasaan kecakapan dan keterampilan tertentu. Dapat dipastikan bahwa guru yang selalu meningkatkan kualitasnya, semakin besar sumbangannya bagi perkembangan siswa dan masyarakat. Guru yang bermutu adalah guru yang mampu berperan sebagai pemimpin di hadapan kelompok siswanya dan juga diantara sesamanya, secara lebih mendasar, guru yang bermutu, giat mencari kemajuan dalam peningkatan kecakapan diri dalam berkarya dan dalam pengabdian sosialnya. 
Secara teknis, guru berkualitas
adalah mampu keterampilan pengajaran secara efektif dan efisien serta mampu membangun motivasi belajar siswanya, mampu berperan dalam layanan bimbingan dan sebagai penilai hasil belajar siswanya.

Profesi guru, dapat diartikan juga sebagai bidang pekerjaan yang dilandasi keahlian atau keterampilan tertentu. Oleh karenanya dalam profesi itu dituntut adanya keahlian dan etika khusus secara baku atau terstandar. Pengertian ini mengandung implikasi bahwa profesi guru hanya dapat dilakukan oleh orang-orang yang secara khusus dipersiapkan untuk itu. Dengan kata lain, profesi guru bukan pekerjaan yang dilakukan oleh mereka yang karena tidak memperoleh pekerjaan lain. Namun demikian banyak diantara guru kurang menyadari atas semua itu. Sehingga secara praktis kebanyakan guru mengalami kesulitan dalam memberikan pelajaran, dalam konteks ini kepala madrasah berupaya melakukan supervisi dengan berbagai alasan.

\section{E. Kesimpulan}

Supervisi dalam pendidikan adalah sebuah kenicayaan, sebab pengelolaan pendidikan pasti memiliki visi dan misi autuk mengembangkan lembaga pendidikannya supaya berkembang maju dan memiliki kualitas yang bagus, supervisor baik yang dari internal (Kepala Madrasah) maupun eskternal yaitu pengawas secara adminstrasi di tunjuk menjadi supervisor mempunyai peranan yang strategis agar cita-cita lembaga madrsah tersebut dapat tercapai.

$$
\text { Madrasah adalah lembaga }
$$

pendidikan berperan sebagai lembaga yang meproses lulusan berkualitas, oleh karena itu peran yang diberikan kepada madrasah harus dilaksanakan oleh tenaga-tenaga yang professional, untuk itu perlu dilakukan supervise agar para guru mnjadi profesonal separti yang dilakukan supervise, antara lain: a. Kunjungan Kelas

b. Pembicaraan individu

c. Demonstrasi mengajar

d. Kunjungan kelas

Keberadaan Kepala madrasah dalam lembaga pendidikan Islam dirasakan penting sekali, bahkan mencapai tingkat urgen, Kepala Madrasah merupakan subjek yang paling diharapkan banyak orang khususnya bawahan atau para guru agar mampu mendorong dan mengantarkan kemajuan lembaganya.

Kondisi ini sangat mungkin terjadi dalamlembaga Islam. Kondisi ini terkait dengan kewenangan dan kepala madrasah. Dari perspektif kewenangan, kepala madrasah memiliki kesempatan seluasluasnya untuk melakukan inovasi dan supervise. Karena kepala madrsah diberikan mandate untuk melakukan kemajuan dan supervise yang konstruktif terhadap para gurunya.

Idialisme kepala madrsah dalam lembaga pendidikan Islam memang harus demikian, Namun sayangnya hingga sekarang ini, masih banyak dan terlalu banyak lembaga pendidikan Islam disebutkan, adanya model-model kepala madrasah atau supervisor (pengawas) justru kurang baik dalam melaksanaakan tugasnya seperti masih feodal, monolit, eksklusif, dominas keluarga, pasif apatis, masa bodoh, dll.

\section{Daftar Kepustakaan}

Adair, John., Pemimpin yang berpusat pada tindakan, Jakarta, Bina

Bafadal, Ibrahim, Supervisi Pengajaran, Teori dan Aplikasinya dalam Membina Profesional Guru, Jakarta BumiAksara, 1992.

Fakultas Tarbiyah dan Ilmu Pendidian IAIN Syekh Nurjati Cirebon,Modul Bahan Ajar Pendidikan dan PelatihanPLPG dan GKMI, tahun 2014

Hidayat, Nurul., Kepemimpinan VisionerKepala Sekolah dalam 
Meningkatkan Mutu Pendikan, Ar.Ruzz Media, $t t$

Komaruddin., Ensiklopedi Manajemen Pendidikan, Bandung

Sagala, Syaeful., Administrasi Pendidikan Kontemporer, Alfabea, Bandung, 2000 .
Siagian P, Sondang., Administrasi Pembangunan, Konsep, Demensi, dan Strateginya, Bumi Aksara, Jakarta,1999

Undang-Undang No. 20 tahun 2003 tentang SISDIKNAS.

Undang-undang No. 14 tahun 2005

tentang Guru dan Dosen 